\title{
THE PROCESS OF RESTRUCTURING MUNICIPALITIES IN TURKEY: AN EMPRICAL STUDY WITH THE MANAGERS OF MUNICIPALITIES ${ }^{1}$
}

\author{
$* * *$ \\ TÜRKIYY'DE BELEDIYYLERIN YENIDEN YAPILANMA SÜRECİ: \\ BELEDIYYE YÖNETİCILERİ İLE AMPİRIK BİR ÇALIŞMA
}

\author{
Prof. Dr. Gülsüm GÜRLER HAZMAN \\ Afyon Kocatepe Üniversitesi \\ İktisadi ve İdari Bilimler Fakültesi \\ Maliye Bölümü \\ gghazman@aku.edu.tr \\ ORCID: 0000-0002-9953-4330
}

\begin{abstract}
Reform studies was carried out that including the quality and effectiveness of the services provided by the municipalities and resolving the existing problems of the local administrations in the administrative and financial sectors. The latest initiative for local governments was initiated by the number of the Law of 6360 dated 2012 and continued with the number of the Law of 6447 dated 2013 in Turkey. The aim of the study is to evaluate the reforms and the results of the regulatory reforms according to municipality managers. It is important to note here that since the day from the Republic to today arrangements in the study, so it is also prevented that the municipality managers are biased. In the study conducted with the municipalities that can represent the population from the provincial, district, metropolitan and metropolitan municipalities and what needs to be done an effective and successful reform of the reform process, and what are the obstacles of this process.
\end{abstract}

Keywords: Reforms in municipalities, Efficiency, Local governments.

Öz

Reform çalışmalarl, belediyeler tarafindan sağlanan hizmetlerin kalitesi ve etkinliği ile yerel yönetimlerin idari ve mali sektördeki mevcut sorunlarının çözülmesini kapsayacak şekilde gerçekleştirilmiştir. Yerel yönetimlere yönelik bu kapsamdaki en son 2012 tarihli ve 6360 sayılı Kanun ile başlatılmış ve 2013 tarihli 6447 sayıl Kanun ile devam etmiştir. Çalışmanın amacı, belediye yöneticileri açısından belediye reformunu ve reform çalışmalarının sonuçlarını değerlendirmektir. Burada belediye yöneticilerinin önyargılı olmasının engellenmesi için Cumhuriyet'ten günümüze kadar olan düzenlemeler ele alınmıştır. Çalışma, il, ilçe, büyükşshir ve büyükşehir belediyeleri ile gerçekleştirilmiş ve reform sürecinin etkili ve başarılı bir şekilde gerçekleştirilmesi için neler yapılması gerektiği ve bu sürecin önündeki engeller üzerinde durulmuştur.

Anahtar Kelimeler: Belediyelerde Reform, Etkinlik, Yerel Yönetimler.

\footnotetext{
${ }^{1}$ This study was supported by the Scientifc Research Projects Committee (project number: 17.KARIYER.29) by the Rectorate of Afyon Kocatepe University, Afyonkarahisar, Turkey

This article was submitted in III. International Multidisciplinary Congress of Eurasia, 2017 and published only as an abstract form.
} 


\section{INTRODUCTION}

The scope of this study is reorganization of local governments in Turkey. Reforms of local governments are on the political agenda in many countries. It is a fact that the specific structures and duties of local governments vary from country to country. Despite these differences, what is common in all countries is the need to effectively present of local services. The need to improve the quality of services locally offered to citizens is a common goal behind reforms (Denters and Rose 2005; Dollery et al.,2008).

With the efforts to restructure the public economy, effective management understanding discussions began to take place in the literature. With the need for an effective public administration, the search for effective government that controls and coordinates performance has increased. For this reason, an accountable and transparent government approach has come to the fore. This requirement applies not only to central government but also to all public administration. The effectiveness of the administration process and the contribution of the results to the targets can be determined by approaching the targets. It is important for municipalities, which are public institutions, to provide quality and active services and to solve the administrative and financial problems in local administrations. For this purpose, after the establishment of the Republic of Turkey with local regulations, it focuses on restructuring and changes in local service provision and planning processes

The restructuring process for municipalities in Turkey are covered by this study. It is aimed to measure the attitudes and perceptions of municipal administrators in the face of the regulations. For this reason, face to face meetings were held with the administrative authorities in the municipality. As the evaluations of the municipal administrators will be taken into consideration in the study, the persons working at administrative level in the municipalities and the questionnaire were interviewed.

The core of reform efforts for local governments is principles such as efficiency, adequate use of resources and accountability. The overall objective is to transform local governments into an effective, efficient and autonomous institution. From this point of view, it will be possible to determine the opinions of the municipal administrators by focusing on the solutions to the problems in this study. The aim of the study is to identify barriers to municipal reforms and to focus on solution proposals for better quality of reform regulations.

\section{THE NEED TO REFORMS IN MUNICIPALITIES AND REORGANIZATION}

When reviewing the literature on local governments and the restructuring process, it has been emphasized that the necessity of performance measurement in the decisions process becomes more effective (Melkers and Willoughby, 2002). In fact, the reorganization of local government is closely related to the provision of certain elements. These elements are;

(1) efficiency and effectiveness in service delivery,

(2) fairness in the tax burden and equal access to the services provided,

(3) public participation and accountability of elected representatives (Razin, 1996: 40).

This process is related with to transformations in their management process (Denters and Rose, 2005). In order to meet the future needs of service production and distribution, new demands have arisen, involving extensive reforms, especially in administrative and operational structures. (Wollman, 2012). The first defense of the necessity of reform in local governments is concerned with the fact that services can be provided more effectively. In local administrations some services are offered more efficiently than central administration.

The efficiency of management process will help managers to improve their understanding of quality in their implementation of all managerial decisions and will provide important results in determining the extent to which the results are achieved, their contribution to the objectives, and the appropriateness of the objectives and strategies (Ghobadian and Ashworth, 1994). All these indicators 
are considered as the process of "measuring the efficiency and results of services and programs in accordance with the rules" as expressed by Hatry (2006).

\section{GOOD GOVERNANCE AND MUNICIPALITIES: RESEARCH BACKGROUND}

The World Bank defines good governance as an attempt to create an institutional environment where citizens among its environment of abuse and build a state on the other hand, interact. Some features and principles of the United Nations Development Programme (1997) dealing with good governance include: participation, transparency, responsiveness, consensus-oriented, responsible, law-oriented and strategic insight.

At the turn of the century, new models of local government emerged, including the principles of good local governance. In this way, good governance has become an important issue in economic and political development debates. Good governance requires mutual interaction between governments and other stakeholders, communicating with citizens on some issues, and accountability when making decisions. Governments have a key role in this network, expecially transparent, accountable, participatory and public relations.

Burris et al. had studied (2007); the strategies for urban governance. They summarized as the maximizing the performance success of the municipality and creating a successful municipal that on international level. In this research, it is seen that decentralization and privatization lead to an increase in the efficiency of public services as well as the improvement of urban services.

In a Kashmir survey, Ebrahimzadeh and Assadian (2013) analyzed and evaluated the realization of good urban governance in Iran. Their findings showed that the three indexes, which include transparency, legitimacy, efficiency and efficiency, were in good urban management index.

Determining the quality of governance requires measuring two successes: (1) improvements in public policy results and (2) improvements in governance principles. In addition, these three principles of governance are widely recognized: transparency, participation and financial accountability are important for good governance (Carcaba et al, 2017: 16).

\section{MUNICIPALITIES IN TURKEY AND REFORM STUDIES FOR LOCAL GOVERNMENTS}

In 1854, the first Turkish municipality to comply with international standards was Istanbul Sehremaneti. In 1857 a second municipality was established which would cover Beyoğlu and Galata. In the Republican period, the municipal law numbered 1580, which was enacted in 1930, provided legislative legislation for municipalities. In 1984 three metropolitan municipalities (Istanbul, Ankara and Izmir) were established. In the following years 12 more were built and in 1993 the number of the metropolitan municipalities was 15 .

At present, the number of municipalities in Turkey; there are 30 metropolitan municipalities, and non-metropolitan municipalities that are city and district municipalities. And also there are district municipalities that linked metropolitan municipalities. There are 51 city municipalities, 400 district municipalities, 519 district municipalities that linked metropolitan municipalities, 397 municipalities that are smaller than district area and the sum of them is 1397.

Some of the most important obligatory duties of municipalites are;

- Public safety

- Cleaning (solid waste collection and disposal)

- Public transportation

- Water supply and sanitation 
- Public works dealing with roads maintenance, drainage, urban planning

- Agriculturel services as parks and veterinary services.

The problems faced by municipalities apply to almost all municipalities are similar. Many arrangements have been made to solve these problems, some of them have been evaluated as successful but some have not achieved the expected success.

The problems that municipalities face today are briefly summarized as follows;

- Duties and powers can not be determined precisely,

- Municipalities are not "transparent",

- Lack of effective control,

- Inadequate municipal revenues,

- Inadequacy of local autonomy,

- Inadequate staffing who has experience,

In the early 2000s, significant changes in the field of local governments have been carried out and the desire to progress in negotiations initiated with the European Union has inspired this reform work. The Law on the Establishment of the Metropolitan Municipality, numbered 5216 in 2004, and the Law on the Establishment of the District in the Metropolitan Municipality Borders, which were enacted in 2005, and the Municipal Law No. 5347, The Metropolitan Municipality Law No. 5216, which was enacted in 2004, has preserved the existing two-level management structure composed of metropolitan and sub-provincial municipalities.

In addition, with the Law No. 5747 issued in 2008, the first stage municipal status within the borders of the metropolitan municipality was terminated and these municipalities were included in the municipality borders and the number of the municipal municipalities was increased. When it comes to 2012; the Law No. 6360 issued brought significant changes in the municipality structure of the metropolitan city. This law has changed the definition of metropolitan. According to the new definition, the metropolitan municipal borders are overlapped with the provincial municipal boundaries and the provincial municipalities of the provinces with a total population of more than 750,000 have been transformed into metropolitan municipalities.

With the Law No. 6360 and the Law No. 6447 of 13 provinces, Ordu province has been brought to the metropolitan municipality status. In the general need of the law, the concept of effective, effective, citizen-centered, accountable, participatory, transparent and as far as possible local management in many developed countries, with changes in the management paradigm, and as values in the foreground.

\section{RESEARCH DESIGN AND METHODOLOGY}

Quantitative research method was preferred in the study. Quantitative studies help to prove or falsify hypotheses based on their causes and consequences. So data consists of statistically analyzed numbers. Data usually consists of questionnaires, interviews, annual or periodic numerical data. In quantitative studies, samples are selected to represent the population from within the population. One of the approaches of quantitative research that is random sampling method was used in the study.

Research population consisted of a total of 1397 municipalities in Turkey. In parallel with the purpose of the study, interviews were conducted with the managers in the administrative offices. While designing the survey, national and international resources were reviewed and opinions of the experts in this field were taken. After invalid questionnaires were eliminated, 924 valid questionnaire forms were taken into consideration. 
The analyzes were performed by SPSS statistical software. Cronbach's Alpha coefficient $(\alpha)$ was calculated as 0.821 in the reliability test. As the result of normal distribution test (KolmogorovSmirnow) $\mathrm{p}<0.05$, the data do not show normal distribution. In addition to the normal distribution test, variance homogeneity test was performed to select the appropriate analysis technique. As a result, $\alpha>$ 0.05 and homogeneity were confirmed.

\subsection{Research Questions and Hypothesis}

Since nonparametric test techniques would be used, initially "the factors that could prevent the achievements of local government reforms" were measured with 11 variables in the questionnaire.

Q1: Is there a significant difference between the municipal managers about the sense of the obstacles dealing with the municipality reforms?

Q2: Is there a significant difference between the municipal managers about the priority features of reforms?

\subsection{Findings of the Research}

When the findings of the research are analyzed, frequency distributions and percentages are given primarily from the demographic variables.

Table 1. General Information of Participants' Demographic Status

\begin{tabular}{|c|c|c|c|c|}
\hline Variable & $\begin{array}{c}\text { Demographic } \\
\text { Statistics }\end{array}$ & Percent & Frequency & Total \\
\hline \multirow[t]{2}{*}{ Gender } & Male & 83 & 766 & \multirow[t]{2}{*}{924} \\
\hline & Female & 17 & 158 & \\
\hline \multirow{3}{*}{$\begin{array}{l}\text { Marital } \\
\text { Status }\end{array}$} & Married & 84 & 770 & \multirow{3}{*}{924} \\
\hline & Single & 14 & 136 & \\
\hline & Divorced & 2 & 18 & \\
\hline \multirow[t]{5}{*}{ Age } & $18-25$ & 3 & 27 & \multirow{5}{*}{924} \\
\hline & $26-30$ & 11 & 98 & \\
\hline & $31-40$ & 26 & 239 & \\
\hline & $41-50$ & 43 & 397 & \\
\hline & $51-65$ & 17 & 163 & \\
\hline \multirow[t]{3}{*}{ Education } & $\begin{array}{l}\text { Primary } \\
\text { education }\end{array}$ & 4 & 37 & \multirow{3}{*}{924} \\
\hline & High school & 23 & 212 & \\
\hline & University & 73 & 675 & \\
\hline
\end{tabular}

We see that $83 \%$ of the participants are male, $17 \%$ are women and the majority are over 40 years old. Again, $73 \%$ of the respondents to the questionnaire, as seen in Table 1, are college and university graduates.

The testing of the differences between the municipal managers based on the difficulties encountered in the reforms with using Kruskall Wallis test. The Kruskall Wallis test is used to compare the measurements of more than two independent groups of independent variables with nonparametric data. These groups are; vice-president, department head and department director.

To test the first hypothesis we have a question;

Q1: Is there a significant difference between the municipal managers about the sense of the obstacles dealing with the municipality reforms?

Sign value was determined as 0,758 with using Kruskall Wallis test and it was determined that there was no significant difference between the municipal managers. The obstacles in front of the 
reform are measured with 11 variables and the value of 0,758 is the result of the test by taking the average of these 11 variables.

If we want to evaluate the result by taking variables one by one; because of the test values are greater than 0.05 it was determined that there was no significant difference between the municipal managers about the obstacles of the municipality reform.

Table 2. The sense of the obstacles dealing with the municipality reforms

\begin{tabular}{|c|c|c|c|c|c|}
\hline & Variables & Groups & $X^{2}$ & $\mathrm{p}$ & Sig.Difference \\
\hline \multirow{33}{*}{ 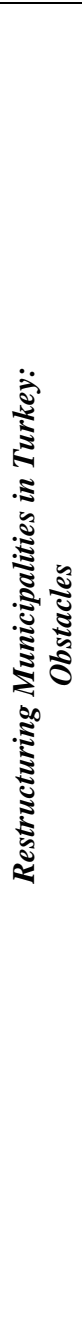 } & \multirow{3}{*}{$\begin{array}{l}\text { The reforms were } \\
\text { designed without long } \\
\text { and planned studies }\end{array}$} & 1:Vice-presindent & \multirow{3}{*}{2,231} & \multirow{3}{*}{0,328} & \multirow{3}{*}{$\begin{array}{l}\text { There is no } \\
\text { significant } \\
\text { difference }\end{array}$} \\
\hline & & 2:Department head & & & \\
\hline & & 3:Department director & & & \\
\hline & \multirow{3}{*}{$\begin{array}{l}\text { Can not complete the } \\
\text { preparations required } \\
\text { for the municipality } \\
\text { reform }\end{array}$} & 1:Vice-presindent & \multirow{3}{*}{0,585} & \multirow{3}{*}{0,746} & \multirow{3}{*}{$\begin{array}{l}\text { There is no } \\
\text { significant } \\
\text { difference }\end{array}$} \\
\hline & & 2:Department head & & & \\
\hline & & 3:Department director & & & \\
\hline & \multirow{3}{*}{$\begin{array}{l}\text { Application examples } \\
\text { are insufficient }\end{array}$} & 1:Vice-presindent & \multirow{3}{*}{2,358} & \multirow{3}{*}{0,308} & \multirow{3}{*}{$\begin{array}{l}\text { There is no } \\
\text { significant } \\
\text { difference }\end{array}$} \\
\hline & & 2:Department head & & & \\
\hline & & 3:Department director & & & \\
\hline & \multirow{3}{*}{$\begin{array}{l}\text { Inadequate staff } \\
\text { training seminars }\end{array}$} & 1:Vice-presindent & \multirow{3}{*}{2,659} & \multirow{3}{*}{0,265} & \multirow{3}{*}{$\begin{array}{l}\text { There is no } \\
\text { significant } \\
\text { difference }\end{array}$} \\
\hline & & 2:Department head & & & \\
\hline & & 3:Department director & & & \\
\hline & \multirow{3}{*}{$\begin{array}{l}\text { Staff training hours are } \\
\text { also insufficient }\end{array}$} & 1:Vice-presindent & \multirow{3}{*}{1,558} & \multirow{3}{*}{0,459} & \multirow{3}{*}{$\begin{array}{l}\text { There is no } \\
\text { significant } \\
\text { difference }\end{array}$} \\
\hline & & 2:Department head & & & \\
\hline & & 3:Department director & & & \\
\hline & \multirow{3}{*}{$\begin{array}{l}\text { Lack of information of } \\
\text { staff trainers }\end{array}$} & 1:Vice-presindent & \multirow{3}{*}{3,397} & \multirow{3}{*}{0,183} & \multirow{3}{*}{$\begin{array}{l}\text { There is no } \\
\text { significant } \\
\text { difference }\end{array}$} \\
\hline & & 2:Department head & & & \\
\hline & & 3:Department director & & & \\
\hline & \multirow{3}{*}{$\begin{array}{l}\text { Staff are less interested } \\
\text { in trainings }\end{array}$} & 1:Vice-presindent & \multirow{3}{*}{0,850} & \multirow{3}{*}{0,654} & \multirow{3}{*}{$\begin{array}{l}\text { There is no } \\
\text { significant } \\
\text { difference }\end{array}$} \\
\hline & & 2:Department head & & & \\
\hline & & 3:Department director & & & \\
\hline & Insufficient expert & 1:Vice-presindent & & & There is no \\
\hline & support for new & 2:Department head & 2,568 & 0,277 & significant \\
\hline & regulations & 3:Department director & & & difference \\
\hline & The training of the & 1:Vice-presindent & & & There is no \\
\hline & staff about new & 2:Department head & 2,495 & 0,287 & significant \\
\hline & $\begin{array}{l}\text { arrangements remains } \\
\text { only theoretical level }\end{array}$ & 3:Department director & & & difference \\
\hline & Lack of central & 1:Vice-presindent & & & There is no \\
\hline & government support in & 2:Department head & 1,320 & 0,517 & significant \\
\hline & $\begin{array}{l}\text { restructuring } \\
\text { municipality }\end{array}$ & 3:Department director & & & difference \\
\hline & Problems with new & 1:Vice-presindent & & & There is no \\
\hline & regulations from long- & 2:Department head & 1,344 & 0,511 & significant \\
\hline & standing practices & 3:Department director & & & difference \\
\hline
\end{tabular}

Thus, there was a consensus on the obstacles of the reforms in municipalities among the participants, both based on the municipalities' managers and the scale of local governments.

The other hypothesis is evaluated with the question of second.

Q2: Is there a significant difference between the municipal managers about the priority features of reforms? Seven basic features have been identified to analyze this hypothesis and these properties are coded as follows;

- Effective auditing should be increased; It is coded as "control",

- Resource requirement should be eliminated; coded as "revenue",

- Compliance with total quality standards; coded as "quality",

- Legal and financial integrity must be ensured; coded as "legal", 
- Autonomy should be increased in certain cases; coded as "local",

- More experienced and skilled personnel should be employed; "expert", "active".

- The importance of performance management for effective and efficient management; coded as

Table 3. Features that the Reforms Must Carry in the Municipalities

\begin{tabular}{|c|c|c|c|}
\hline Variable & & Frequency & Percent \\
\hline \multirow[t]{5}{*}{ Control } & 1:Strongly disagree & 15 & 1,6 \\
\hline & 2: Disagree & 60 & 6,5 \\
\hline & 3:No idea & 17 & 1,8 \\
\hline & 4:Agree & 378 & 40,9 \\
\hline & 5:Strongly agree & 454 & 49,1 \\
\hline \multirow[t]{5}{*}{ Revenue } & 1:Strongly disagree & 5 & 0,5 \\
\hline & 2: Disagree & 44 & 4,8 \\
\hline & 3:No idea & 32 & 3,5 \\
\hline & 4:Agree & 437 & 47,1 \\
\hline & 5:Strongly agree & 406 & 44,1 \\
\hline \multirow[t]{5}{*}{ Quality } & 1:Strongly disagree & 4 & 0,4 \\
\hline & 2: Disagree & 37 & 4,0 \\
\hline & 3:No idea & 40 & 4,3 \\
\hline & 4:Agree & 474 & 51,4 \\
\hline & 5:Strongly agree & 368 & 39,9 \\
\hline \multirow[t]{5}{*}{ Legal } & 1:Strongly disagree & 41 & 4,5 \\
\hline & 2: Disagree & 147 & 15,8 \\
\hline & 3:No idea & 58 & 6,3 \\
\hline & 4:Agree & 371 & 40,4 \\
\hline & 5:Strongly agree & 307 & 33,1 \\
\hline \multirow[t]{5}{*}{ Local } & 1:Strongly disagree & 17 & 1,8 \\
\hline & 2: Disagree & 85 & 9,2 \\
\hline & 3:No idea & 35 & 3,8 \\
\hline & 4:Agree & 331 & 35,8 \\
\hline & 5:Strongly agree & 455 & 49,2 \\
\hline \multirow[t]{5}{*}{ Expert } & 1:Strongly disagree & 7 & 0,8 \\
\hline & 2: Disagree & 39 & 4,2 \\
\hline & 3:No idea & 29 & 3,0 \\
\hline & 4:Agree & 413 & 44,7 \\
\hline & 5:Strongly agree & 437 & 47,3 \\
\hline \multirow[t]{5}{*}{ Active } & 1:Strongly disagree & 14 & 1,4 \\
\hline & 2: Disagree & 43 & 4,6 \\
\hline & 3:No idea & 23 & 2,5 \\
\hline & 4:Agree & 430 & 46,6 \\
\hline & 5:Strongly agree & 414 & 44,9 \\
\hline
\end{tabular}

The answers of the municipal managers who participated in the survey show that the municipalities need to have efficiency in supervision because $89 \%$ of the respondents think that the municipalities need to be effective in supervision. A similar situation also can be seen the question of the necessity and importance of total quality applications. Here too, a large proportion of participants $(91 \%)$ emphasized the importance and necessity of total quality applications in municipalities, with a large proportion of participants (92\%) particularly about the importance of performance management.

It is mentioned that the necessity of all the regulations carried out from the past to the present according to municipal managers in Turkey. In this framework it was possible to observe the consequences of the arrangements made to address the existing problems of the municipalities. 
Therefore, it was possible that outcomes and effectiveness of the reforms in Turkey to make the administrative and financial management structure of the municipalities more regular.

\section{CONCLUSION}

Concepts such as efficiency, frugality, efficiency and performance started to take place in the public sector. Effective management initiatives have begun in public institutions, with good practice examples especially applicable to the private sector, and researches and regulations have been carried out at the reform level. In the restructuring process of the local governments, it has been emphasized that the management should be more effective and the importance and importance of the performance measurement with the decisions taken together with the priorities.

Designed to work with Turkey in the reform of the results of arrangements aimed to evaluate the obstacles and advantages in municipalities by the municipal executives. It is important to note here; the day-to-day regulations in the study were addressed and the municipality managers were also prevented from being side-by-side. Since the evaluations of the municipal administrators will be taken into consideration in the study, interviews have been made with the persons who are working in administrative positions in the municipalities. The necessity and importance of all the regulations from the past to the present day and their success or failure will be evaluated by the municipal administrators. In this framework it was possible to observe the results of the arrangements made to address the existing problems of the municipalities. Thus Turkey in the municipality of administrative and financial management structure that will make more regular nature of the arrangements made in the nature of the reform, it has been possible to evaluate the results and events through the eyes of local actors.

According to the results of the study, municipalities have serious resource constraints because $73.7 \%$ of the survey respondents stated that the municipalities are experiencing resource constraints. However, most of the participants consider the lack of expert staff in municipalities as a problem. Ana also $70 \%$ of the participants think that they do not have as much administrative autonomy as the municipalities and are often governed by political concerns. The responses to the questionnaires indicate that the municipalities need to have efficiency in supervision, because $89 \%$ of the respondents think that the municipalities need to be actively supervised. A similar situation also raises the question of the necessity and importance of total quality applications. Here, too, a large proportion of participants (91\%) emphasized the importance and necessity of total quality practices in municipalities, with a large proportion $(92 \%)$ of participants especially about the importance of the transition to performance management.

Three elements of administrative quality, which are important in the success of the reforms for municipalities, have been identified; significant divergence between municipal officials on important issues for the success of reform studies in municipalities; The second (department head) and third (branch manager) groups are concerned with the "central authority support is important" change. In general, it has been observed that there are no significant differences and mostly agree with the hypothesis questions that are evaluated at different angles between municipality managers. This shows that for municipalities they have the same viewpoints as what is needed for restructuring, what is important and what is priority. Remaining consensus on the problems and suggestions by the administrators will affect the success of the planned studies positively.

\section{REFERENCES}

BURRISS, S. T., HANCOCK, L. V. and HERZOG, A. (2007). "Emerging Strategies for Healthy Urban Governance", Journal of Urban Health Bulletin of the New York Academy of Medicine, 84(1): 154-163.

CARCABA, A. GONZALES, E., VENTURA, J. and ARRONDO, R. (2017). "How Does Good Governance Relate to Quality of Life?", Sustainability, 9(631): 2-16. 
DENTERS, B. and ROSE, L. E. (2005). Comparing Local Governance, Trends and Developments, Basingstoke: Palgrave MacMillan.

DOLLERY B. E., CARCEA J. and LESAGE E. E. (2008). Local Government Reform. A Comperative Analysis of Advanced Anglo- American Countries, Northampton: Edward Edgar Publishing.

EBRAHIMZADEH, I. and ASSADIAN, M. (2013). "Analyze and Evaluate the Extent of Realization of Urban Good Governance in Iran Case Study: Kashmar City”, Journal of Geography and Urban Planning Reoginal, 6 .

GHOBADIAN, A. and ASHWORH, J. (1994). "Performance Measurement in Local Government Concept and Practice", International Journal of Operations \& Production Manegement, 14(5): $35-51$.

HATRY, H. P. (2006). Performance Measurement, The Urban Institute Pres, 2 nd edition, Washington.

MELKERS, J. and WILlOUGHBY, K. (2002). Evolving Performance Measurement in Local Government, Draft- Meeting of the ABFM, Kansas City.

RAZIN, E. (1996). "Municipal reform in the Tel Aviv metropolis: Metropolitan government or metropolitan cooperation?, Environment and Planning C", Government and Policy, 14: 39-5.

WOLLMAN, H. (2012). "Local Government Reforms in (seven) Europen Countries: Between Convergent and Divergent, Conflicting and Complementary Developments", Local Government Studies, 38: 41-70. 